\title{
Adaptation of the STEM Value-Expectancy Assessment Scale to Turkish Culture
}

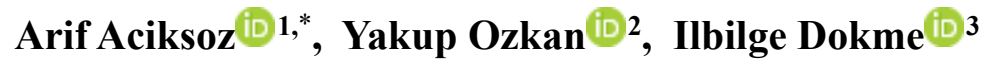 \\ ${ }^{1}$ Ministry of National Education, 42060, Konya, Turkey \\ ${ }^{2}$ Ministry of National Education, 06620, Ankara, Turkey \\ ${ }^{3}$ Department of Science Education, Faculty of Education, Gazi University, Ankara, Turkey
}

\author{
ARTICLE HISTORY \\ Received: Oct 252019 \\ Revised: Mar 212020 \\ Accepted: Apr 082020 \\ KEYWORDS \\ STEM, \\ STEM Education \\ Expectancy-Value \\ Theory, \\ Scale Adaptation
}

\begin{abstract}
This study aimed to obtain a measurement tool in Turkish culture to determine the motivation of university students (pre-service teachers) toward STEM based on the expectancy-value theory. For this purpose, the validity and reliability studies of the Turkish version of the STEM Value-Expectancy Assessment Scale developed by Appianing and Van Eck (2018) were conducted. A confirmatory factor analysis (CFA) was undertaken to check the validity of the scale administered to 196 pre-service science teachers selected by purposeful sampling and Cronbach's alpha internal consistency coefficients were examined for the reliability evaluation. One item that showed a tendency to be loaded on two factors in CFA was removed, and the repeated CFA confirmed a good fit for the two-factor structure as in the original scale. In the reliability analysis, the internal consistency coefficients were calculated as .87 for the whole scale, .82 for the perceived value component, and .82 for the expectations of success in STEM careers component. When the validity and reliability results were evaluated together, it was concluded that the adaptation of the scale to Turkish culture was measurement tool that has high validity and reliability that could be administered to prospective teachers.
\end{abstract}

\section{INTRODUCTION}

The developments in society and economy increase the need for individuals who research, question, create solutions for problems they encounter, associate the information with daily life and participate in production (Altunel, 2018; Ananiadou \& Claro, 2009; Morrison, 2006; Saavedra \& Opfer, 2012). These abilities, required by the 21 st century, are related to what individuals can do with the information they have and how they apply what they have learned in authentic contexts, they should be considered as an education which is supposed to be integrated to into curriculum, not as "another thing to be taught" (Larson \& Miller, 2011). Thus, education systems should be equipped in a way to reveal the interests and abilities of individuals, to provide them to benefit from the new forms of socializing, contribute to 
economic growth actively and to ask questions and conduct researches (Ananiadou \& Claro, 2009; MEB, 2017).

Today, STEM (Science, Technology, Engineering, and Mathematics) education, which is considered to be interdisciplinary, has come to the forefront as an innovative approach to education that aims to raise individuals who can meet the challenges of the twenty-first century. In the STEM approach, the education on science, technology, engineering and mathematics is presented in an integrated manner and associated with daily life (Y1ldirım, 2018). This approach enables individuals to overcome the challenges of the century. In this process, students first learn about science and mathematics, then acquire an understanding of how these two disciplines work in the fields of technology and engineering, and develop deep technical and personal skills (Bybee, 2010). Additionally, in this day when the economic success gradually depends on the creation and application of knowledge, students possess valuable skills such as the skeptical and delicate analysis of evidences and theories, evidence-based thinking, development of logical arguments and problem solving (West, 2012). Therefore, STEM education is vital in not only supporting the necessary participation in labor force but also succeeding in global competition in the rapidly developing world (Breiner, Harkness, Johnson, \& Koehler, 2012).

The reform movements, initiated in the United States to create workforce in STEM fields, have been being implemented with the participation of many educational communities (American Association for the Advancement of Science, National Research Counsil, National Sanitation Foundation etc.) for more than 20 years (MEB, 2016; Sanders, 2009). However, despite such reforms, serious difficulties are still encountered in STEM education. One of the most important problems is that STEM education cannot motivate students to acquire sufficient knowledge and skills to meet the challenging economic and leadership needs of the century (Hossain \& Robinson, 2012). In particular, the inadequacy of teachers in applying STEM causes students to develop a negative attitude toward related fields, and at the beginning of their education, they become convinced that STEM subjects are very difficult to learn or uninteresting. This results in a shift in students' occupational choices from STEM to other fields (National Science Board, 2007; PCAST, 2010).

Increasing and continuing interest in STEM is of paramount importance as the need for monitoring STEM career paths increases day by day (Romine \& Sadler, 2016). This requires students being encouraged to move toward careers in STEM fields (Akgündüz et al., 2015). The relationship between students' motivation and STEM career choices is an important issue in promoting STEM careers (Rosenzweig \& Wigfield, 2016). Because the motivation of students directly affects their decision whether to enter an education path that will provide access to a career in a STEM field (Chen \& Dede, 2011; Wang, 2013).

\subsection{Theoretical Framework}

Motivation, generally considered as a way of mobilizing individuals, is defined by social scientists as a psychological process that stimulates, guides, and sustains a behavior in a more technical manner (Mitchell, 1982). In other words, it is a great source of power that affects the direction, amount, and continuity of students' behaviors toward their goals (Akbaba, 2006). Academically motivated students set goals for themselves, make plans, and endeavor to realize these goals (Ekeh \& Njoku 2014). Believed to be a vital determinant of academic performance and success, motivation is an important factor to take into consideration in education (Joseph, Anikelechi \& Marumo, 2019).

Motivation is a meta-concept that includes a number of related concepts, such as participation, persistence, interest, self-efficacy, and self-concept. As a meta-concept, it also involves a wide range of theoretical constructs, including expectancy-value or internal-external and many 
related theories concerning self-efficacy, goal, intelligence, choice, and self-determination (Irvine, 2018). Among these examples, the expectancy-value theory is considered to be one of the most important theories related to the nature of achievement motivation (Wigfield, 1994). Consisting of two main components, expectancy beliefs and subjective task value, this theory suggests that individuals' preferences, persistence, and performance can be explained by their beliefs about how well they will perform and how they value the activity (Eccles \& Wigfield, 2002; Gråstén, 2016; Wigfield, 1994). In this respect, motivation for the achievement of a task to be performed in a context should be considered as the sum of the value given to this task and the reward expectations related to this task (Tünkler, 2018; Sarısepetçi, 2018).

The expectancy beliefs component of the expectancy-value theory refers to the beliefs of students concerning how well they will perform an activity in the short and long term (Appianing \& Van Eck, 2018). Vroom (1964), one of the pioneers of the expectancy theory, defined expectation as a temporary belief that a certain action would result in a specific purpose and emphasized that beliefs might change over time (Onaran, 1981:73). Researchers also argue that this component overlaps with an individual's self-efficacy perception (Appianing \& Van Eck, 2018; Irvine, 2018; Wigfield \& Eccles 2000). Self-efficacy is the judgment of individual concerning his/her belief in being able to organize and conduct actions necessary to manage possible situations (Bandura, 1995:2). An individual with high self-efficacy is more willing to make greater efforts and work harder in the face of failure and difficulties than a person who doubts his/her abilities (Titrek, Çetin, Kaymak \& Kaşıkçı, 2018). An individual's belief in selfefficacy is influenced by indirect experience (observing the experiences of others), verbal persuasion (being verbally motivated by others), mastery experience (achievements and failures), and physiological and affective situations (Tschannen-Moran \& McMaster, 2009).

Subjective task value, the second component of the expectancy-value theory, expresses the importance or meaning an individual attribute to a certain task, and in a way, the incentives for performing that task (Gråstén, 2016; Putwain, Nicholson, Pekrun, Becker, \& Symes, 2019). Eccles (2005a) defined subjective task value as the quality of a task that contributes to an increase or decrease in the possibility of an individual's choice and suggested that this component was composed of four sub-components: attainment/importance value, intrinsic value, utility value, and relative cost value (Eccles 2005a; Eccles, 2005b; Eccles \& Wigfield, 2002; Wigfield \& Eccles, 2000) which are explained in detail below.

Attainment value refers to the importance of performing a task or activity or completing a given job for a student (Ecless \& Wigfield, 2002; Irvine, 2018; Patridge, Brustad, \& Stellino, 2013; Wigfield, 1994). This value is related to the suitability of the given task or activity to the selfidentity of the person (Eccles, 2005b). To clarify, an individual who encounters a task or activity that suits his/her identity will tend to perform it in the best way possible by attaching greater personal attention to it. The high importance value held by a student supports their performance despite possible low expectations of success and provides greater participation in course tasks and activities (Putwain et al., 2019).

Intrinsic value is related to the immediate and naturally occurring pleasure (amount of satisfaction) that a person receives or hopes to receive by performing a task or activity (Eccless, 2005b, Patridge et al., 2013). This component, also described as an individual's subjective interest in a subject, is similar to the concept of intrinsic motivation in some respects, but these two concepts are not identical (Eccles, 2005a; Nagy, Trautwein, Baumert, Köller, \& Garrett, 2006; Wigfield, 1994). As explained in the self-determination theory, in cases with high intrinsic value, the intrinsic value component may be seen as similar to intrinsic motivation because positive psychological results present as a reward (Meyer, Fleckenstein, \& Köller, 2019). 
Utility value refers to how much a task is related to an individual's current or future goals, including career goals (Patridge et al., 2013; Wigfield, 1994). If an individual believes that a task is important for his/her life, such as "I need to take extra courses to attend medical school", utility value increases (Harackiewicz, Rozek, Hulleman, \& Hyde, 2012). In this component, the status of engaging in a task is not related to the individual's inner desire but his/her willingness to reach the desired final state (Wigfield \& Eccles, 2000). Therefore, it is similar to the structure of external motivation. Simple external interventions on utility value, such as parental encouragement of their offspring's academic efforts can influence this value (Harackiewicz et al., 2012).

Relative cost value, the final component of subjective task value, refers to what a person should compromise on (e.g., doing biology homework instead of watching movies) or sacrifice (e.g., effort, time, and pleasure) to complete a task (Appianing ve Van Eck, 2018; Irvine, 2018). This value is a negative component for the motivation of an individual and decreases the value of the task (Tünkler, 2018). Relative cost value is affected by many psychological states related to the performance of a task, such as anxiety or fear of failure, rejection or discrimination by peers, or anger/disappointment of parents (Eccles, 2005a; Patridge et al., 2013).

\subsection{Significance of the Study}

The students' orientation toward STEM fields and their sustained efforts in these fields are reflected as a whole of their expectations of success and perception of value. STEM, having an important position in today's world, is influenced as much by the expectations and values of teachers in the education field as those of students. Thus, teacher motivation in the field is one of the important factors that affect student motivation because a motivated teacher both encourages students in his/her class to have high expectations and values and promotes the implementation of educational reforms at an advanced level (Yazic1, 2009). For this reason, it is very important to measure not only students' but also teachers' expectations and perceptions of success (motivation) to provide high-quality STEM education, which is considered a new reform in the educational field.

The literature contains several studies based on the expectancy-value theory. For example, Burak (2014) examined the motivation of students in the musical instrument learning process using a questionnaire while Tünkler (2018) investigated students' expectations and value perceptions of the social studies course using an inventory developed by Eccles and Wigfield (1995) that the author adapted to the social studies context. Sarısepetçi (2018) developed an achievement motivation scale based on Eccles' theory of achievement motivation and adapted it for middle school students. In another study, Barutcu (2017) examined how the workplaces prepared according to the principles of expectation-value theory affect students' writing skills and motivation with action research, which is one of the qualitative research methods. However, to the best of our knowledge, the Turkey literature contains limited studies and no scales taking the expectancy-value theory as a basis to determine university students' expectations and perceived value of STEM education. Thus, it is hoped that this adaptation study will make an important contribution to the literature by introducing a tool to measure the values and expectations of prospective teachers related to STEM.

\subsection{Purpose of the Study}

This study aimed to implement the adaptation of The Value-Expectancy STEM Assessment Scale (VESAS) to Turkish culture developed by Appianing and Van Eck (2018) to determine the motivation of pre-service science teachers about STEM in higher education. 


\section{METHOD}

This section presents information on the sample, original scale, and process of adaptation of the scale to Turkish culture, administration of the adapted version to the sample, and analysis of the data obtained.

\subsection{Sample}

In this study, the research population consists of 12435 females and 3851 males, in total 16286 preservice teachers, from the Science Education Department of Faculty of Education at 66 universities as of 2019. Scale has been applied at two universities (Gazi and Çanakkale Onsekiz Mart Universities) chosen randomly in this population. The original population of the scale was consisted of female students who continue to STEM programs or who left the STEM programs after participating at least one semester. For this reason, criterion sampling which is one of the purposeful samplings is used in order for the scale items to work correctly. It is determined as a criterion that preservice teachers who will answer the adapted scale take at least one semester STEM lecture or course. According to this criterion, 196 preservice teachers, including 166 females and 30 males, filled the scale. The scale filling rate of the chosen universities has been calculated as $29.2 \%$. The range of the preservice teachers is shown in Table 1 .

Table 1. Frequency table showing the gender distribution of the sample

\begin{tabular}{|c|c|c|c|c|}
\hline Gender & Grade & Frequency & Total Frequency & Percentage \\
\hline \multirow{4}{*}{ Male } & 1 & 6 & \multirow{4}{*}{30} & \multirow{4}{*}{15.3} \\
\hline & 2 & 12 & & \\
\hline & 3 & 5 & & \\
\hline & 4 & 7 & & \\
\hline \multirow{4}{*}{ Female } & 1 & 22 & \multirow{4}{*}{166} & \multirow{4}{*}{84.7} \\
\hline & 2 & 65 & & \\
\hline & 3 & 39 & & \\
\hline & 4 & 40 & & \\
\hline TOTAL & & & 196 & 100 \\
\hline
\end{tabular}

As it is seen in Table 1, the reason that the sample largely consists of female students is that the preservice teacher population consists of $76 \%$ female and $24 \%$ male. In this regard, a rate close to the population has been achieved.

Although there is no definite opinion on the sample size in the confirmatory factor analysis, Kline has stated that it should be 10 times of the number of items take place in the scale. Since the original scale consisted of 15 items, 166 female students formed a sufficient size for analysis. However, since the increase in the sample size affects the fit indexes, it is examined whether there is a significant difference between male and female preservice teachers who filled the scale. As a result of the independent sample t-test, no significant difference has been found (Table 2).

Tablo 2. Independent sample t-test results according to the average of scale scores

\begin{tabular}{lcccccc}
\hline Group & $\mathrm{N}$ & $\overline{\mathrm{x}}$ & $\mathrm{SD}$ & $t$ & $\mathrm{df}$ & $p$ \\
\cline { 1 - 4 } Famale & 166 & 4.0111 & .52291 & -1.260 & 194 & .209 \\
\cline { 1 - 6 } Male & 30 & 4.1389 & .50901 & & & \\
\hline
\end{tabular}

Thus, although the original scale was only applied to female students, based on the t-test results no gender discrimination has been observed in this study, and the sample consists of 196 preservice teachers. 


\subsection{Original Value-Expectancy STEM Assessment Scale}

The fact that the students who enroll in STEM programs in the USA have a high rate of leaving these programs and that more than half of the students who leave are the females, create need for the academicians to understand why they leave the programs. Appianing and Van Eck (2018) aimed to develop a valid and reliable scale in order to measure the values and expectations of females regarding their participation, attendance or renounce decisions for STEM programs.

The original scale based on the expectancy-value theory of Eccles, a motivation theory, was developed in 2015 by the same researchers to measure motivations for information and communications technology (ICT) and was adapted from 22-item Likert type VIES - Value Interest Expectancy Scale. The scale, which was adapted to STEM, is applied to two groups of females in universities located in the middle west of the USA. The first group consists of female students who have completed at least one semester in the STEM program or who have stayed in the STEM program, and the second group consists of female students who have been enrolled in the STEM program for at least one semester but left. 356 students (297 students first group, 59 students second group), who complete the online scale delivered through e-mail to randomly chosen 2055 students, form the sample.

The researchers have conducted Kaiser-Meyer-Olkin (KMO) and Bartlett's test of sphericity to determine whether the 22-item Likert type scale applied to 356 students is suitable for factor analysis or not. The KMO value is found to be .96 and the Bartlett test of sphericity is found to be $p<0.05$, based on these results it is seen that the sample is sufficient for factor analysis test. As a result of factor analysis, a two-factor structure, which consists of 14 items of which factor loads range between .41 and .97 and 8 items of which factor loads range between .48 and .86 , has been found. These two factors have explained $62.29 \%$ of the variance. Researchers who see the Cronbach Alpha values for the internal consistency of the scale have found that the reliability coefficient of the first factor to be .95 and the second factor to be .90 . Since the reliability coefficient of the first factor is over .90, the correlations of the items under the factor have been examined and 7 similar items have been excluded from the scale. It has been observed that the two-factor structure formed as a result of the renewed factor analysis explains $61.49 \%$ of the total variance, the factor loads in the first factor range between .51 and .91 and the factor loads in the second factor range between .65 and .88. The Cronbach Alpha value of the "Perceived Value" component made on 15 items, 7 of which are inverted, is found to be .90, while The Cronbach Alpha value of the "Expectation of Success in STEM career" component is found to be .89 .

\subsection{Adaptation of VESAS to Turkish Culture}

Motivation of teachers for a field is a factor that affects the motivation of their students for this field. In this respect, since it is thought that it will contribute to the development of STEM education in our country, the adaption of STEM Value-Expectancy Asssessment Scale of Appianing and Van Eck (2018), which is based on expectancy-value theory of Eccles, a motivation theory, has been decided to be adapted. In the adaptation study, the adaptation stages specified by Hambleton and Patsula (1999) have been taken into consideration. First, the researchers have been contacted by e-mail and their permissions have been asked in ethical aspect to in relation to adapt the scale to Turkish culture. After obtaining the permission of the researchers, the adaptation process has started.

Because the basic structure desired to be measured on the scale developed by Appianing and Van Eck (2018) is STEM motivation, the scale was studied with a group of three people with language competencies, two of them have taken STEM education and one of them is a STEM specialist. It has been agreed that this structure is in our culture and that it is perceived jointly 
in different cultures. Therewith, the scale items have been then translated from English to Turkish one by one by the same group, considering their cultural characteristics, and the translated materials have been discussed comparatively especially in terms of cultural compatibility. For instance, the statement of "I dislike STEM courses" has been adapted as "I dislike the courses in STEM field" since there is no STEM course directly in our culture.

The final translations of the items were obtained based on consensus and written in both English and Turkish on the scale adaptation form. Then, 10 English teachers were asked to rate the translations from 0 to 5 . In addition, below each item was added the question, "How would you translate it?" to gain the contributions of teachers to the adaptation process. The forms were collected, and the mean scores given by the teachers to the translation of the items were calculated (Table 3).

Table 3. Mean scores of the translated items

\begin{tabular}{cccc}
\hline Item number & Mean score & Item number & Mean score \\
\hline 1 & 5.0 & 9 & 5.0 \\
\hline 2 & 4.9 & 10 & 4.7 \\
\hline 3 & 4.7 & 11 & 4.9 \\
\hline 4 & 4.9 & 12 & 4.9 \\
\hline 5 & 4.8 & 13 & 4.8 \\
\hline 6 & 4.5 & 14 & 4.8 \\
\hline 7 & 4.9 & 15 & 4.2 \\
\hline 8 & 4.9 & & \\
\hline
\end{tabular}

In scale adaptation studies, a rate of agreement of more than $80 \%$ consistency in the translation of items made by different individuals is considered appropriate (Crocker \& Algina, 1986, as cited in Haciömeroğlu \& Bulut, 2016). The evaluation revealed that the translation score ranged from 4.2 to 5.0, indicating that the items had been accurately translated considering the original version and there was a high agreement (over $80 \%$ ) between the translators and reviewers. The Turkish version of the scale, confirmed to be equivalent to the original English scale in terms of language, was proofread by a Turkish language teacher, and its comprehensibility was confirmed through the examination of five doctoral students. According to their feedback, the necessary revision was undertaken, and the final version of the scale was obtained.

\subsection{Administration of the Adapted Scale}

The final Turkish version of VESAS was administered to pre-service teachers in one lesson, in which there was high student participation and motivation during the academic year according to the academicians that gave the courses. Prior to the administration of the scale, the academicians were informed about STEM and the scale. The students were encouraged to be sincere in their responses to the scale items, and sufficient time was given for them to complete the scale.

\subsection{Data Analysis}

The data obtained during the adaptation process of the scale were entered into IBM SPSS Statistics program v. 22.0, the reverse items were corrected, and values were assigned to missing data. Then, a confirmatory factor analysis (CFA) was performed to test the construct validity of the scale. In order to verify the two-factor structure determined by the researchers who developed the original scale in the analysis, a path diagram was constructed and its suitability to the factor structure was checked by examining the standardized loads and $t$-values, as well as the fit indices. In addition, recommendations for modification were taken into consideration to increase the fit of the model. In order to determine the reliability of the scale, Cronbach's alpha internal consistency coefficients of the whole scale and the factors were 
analyzed. $p<0.05$ level was used to evaluate the statistical significance of all analyzes performed in this study.

\section{FINDINGS}

\subsection{Validity of the Adapted Scale}

The results obtained from CFA revealed that the standardized loads varied between .42 and .85 and the t-values were significant at the .01 level. Although some of the fit indices obtained from the first analysis showed a good fit ( $\mathrm{x}^{2} / \mathrm{df}-2.92$, SRMR-.080, AGFI-.82, NFI-.91, IFI-.94), others only had values indicating an acceptable fit (RMSEA-.09, NNFI-.92, Since CFI-.93, GFI-.87); therefore, modification recommendations were sought. According to this, high modification was recommended for item 12 under the expectations of success component. The tendency of this item, which was theoretically aimed to measure the perceived value latent variable, to load on the expectations of success component led to a decrease in the fit of the model. Thus, this item was removed from the scale after obtaining expert opinion. In the second CFA analysis conducted following the exclusion of item 12 from the scale, the recommended modification between items 8 and 10 under the expectations of success component was rechecked. This modification was also performed in order to further increase the model fit. After applying the necessary modifications, the final CFA was conducted, and the results of standardized loads and t-values are presented in Table 4.

Table 4. Standardized loads and t-values

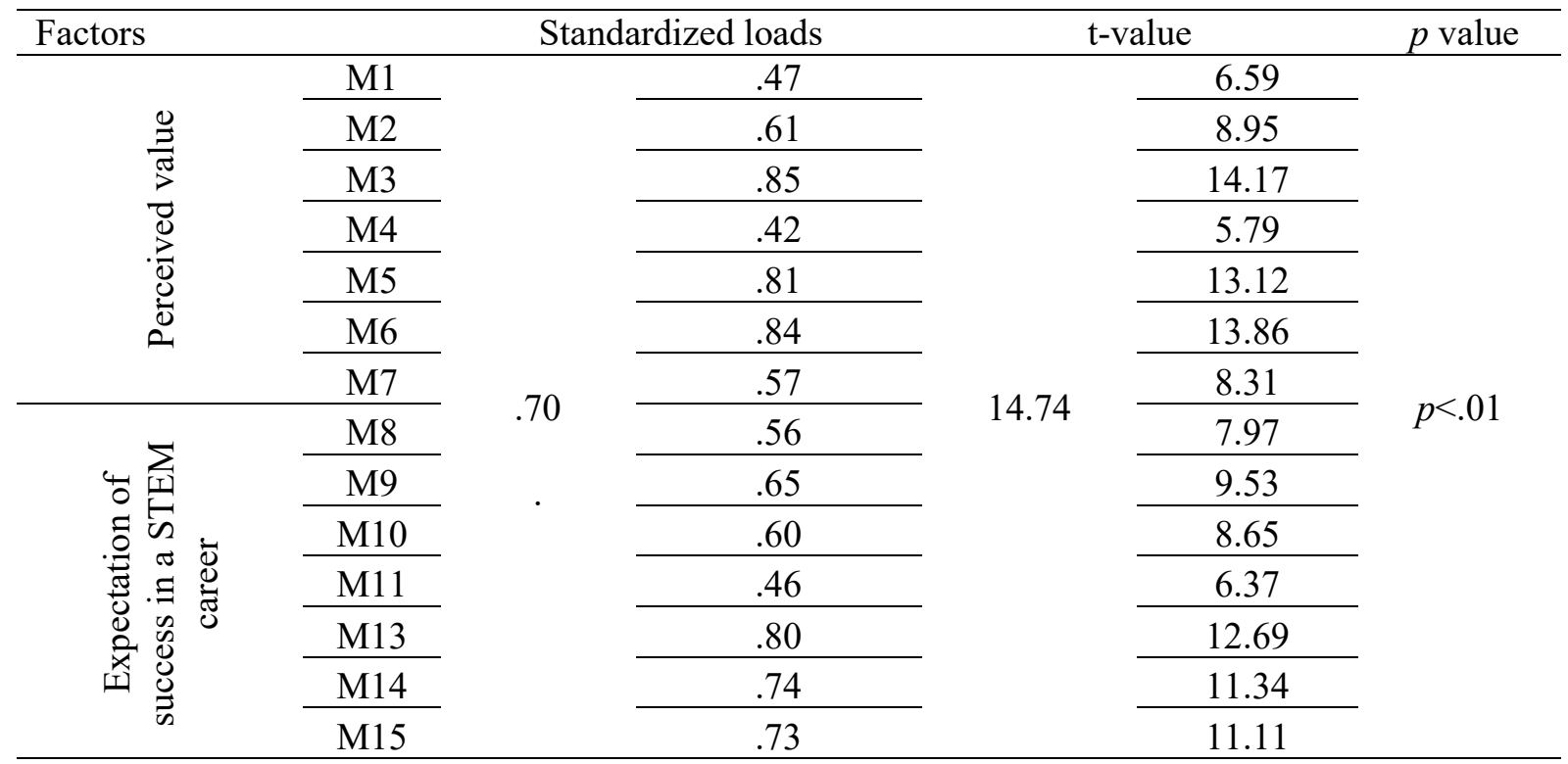

The standardized factor loads in CFA show how much the latent variable is represented by the observed variable. As shown in Table 3, the standardized factor loads varied between .42 and .85. for the adapted scale. This means that the perceived value component was least represented by item 4 with a factor load of .42 and most represented by item 3 with a factor load of .85 . The second component (expectations of success in STEM careers) was represented least by item 11 and most by item 13 with factor loads of .46 and .80 , respectively. In addition, non-significant t-values should be excluded from the analysis (Çokluk et al., 2012), but as shown in Table 3, all $\mathrm{t}$-values were significant at the .01 level. The fit indices obtained from the analyses and their critical values are given in Table 5 according to the measures used.

An examination of the data in Table 4 shows that the IFI and CFI values indicated a perfect fit, while the value obtained by dividing the square value $(\chi 2)$ by the degree of freedom (df) and the SRMR, NFI and NNFI values were close to a perfect fit. Since the values of all the 
remaining fit measures (RMSEA, GFI, and AGFI) were above the critical level, the model was considered to have a good fit.

Table 5. Fit indices and their critical values

\begin{tabular}{ccccc}
\hline Fit measure & Perfect fit & Acceptable fit & $\begin{array}{c}\text { Fit values of the } \\
\text { research }\end{array}$ & Conclusion \\
\hline $\mathrm{X}^{2} / \mathrm{df}$ & $0 \leq \chi^{2} / \mathrm{df} \leq 2$ & $2<\chi^{2} / \mathrm{df} \leq 3$ & 2.1 & Acceptable \\
\hline RMSEA & $0 \leq \mathrm{RMSEA} \leq .05$ & $.05<\mathrm{RMSEA} \leq .08$ & .075 & Acceptable \\
\hline $\mathrm{CFI}$ & $.97 \leq \mathrm{CFI} \leq 1.00$ & $.95 \leq \mathrm{CFI}<.97$ & .97 & Perfect fit \\
\hline IFI & $.95 \leq \mathrm{IFI} \leq 1.00$ & $.90 \leq \mathrm{IFI} \leq .95$ & .97 & Perfect fit \\
\hline GFI & $.95 \leq \mathrm{GFI} \leq 1.00$ & $.90 \leq \mathrm{GFI}<.95$ & .90 & Acceptable \\
\hline NFI & $.95 \leq \mathrm{NFI} \leq 1.00$ & $.90 \leq \mathrm{NFI}<.95$ & .94 & Acceptable \\
\hline AGFI & $.90 \leq \mathrm{AGFI} \leq 1.00$ & $.85 \leq \mathrm{AGFI}<.90$ & .85 & Acceptable \\
\hline NNFI & $.97 \leq \mathrm{NNFI} \leq 1.00$ & $.95 \leq \mathrm{NNFI}<.97$ & .96 & Acceptable \\
\hline SRMR & $0 \leq \mathrm{SRMR} \leq .05$ & $.05<\mathrm{SRMR} \leq .10$ & .058 & Acceptable
\end{tabular}

(Çapık, 2014; Kline, 2011; Schermelleh-Engel, Moosbrugger, Müler, 2003; Sümer, 2000)

\subsection{Reliability of the Adapted Scale}

Cronbach's alpha internal consistency coefficient and reliability analyses of the adapted scale were performed. The internal consistency coefficients, corrected item-total relationship, and the alpha values after correction were analyzed for each factor and the whole scale, and the findings are shown in Table 6.

Table 6. Cronbach's alpha coefficients of the factors and scale

\begin{tabular}{|c|c|c|c|c|c|c|}
\hline Item & $\begin{array}{l}\text { Cronbach's } \\
\text { Alpha }\end{array}$ & $\bar{X}$ & $\mathrm{~S}$ & $\begin{array}{l}\text { Corrected Item- } \\
\text { Total Correlation }\end{array}$ & $\begin{array}{c}\text { Cronbach's Alpha } \\
\text { Value After } \\
\text { Correction }\end{array}$ & $\begin{array}{c}\text { Cronbach's } \\
\text { Alpha of the Scale }\end{array}$ \\
\hline \multicolumn{7}{|c|}{ Perceived value } \\
\hline M1 & \multirow{7}{*}{.82} & 4.61 & .68 & .462 & .81 & \multirow{7}{*}{.87} \\
\hline M2 & & 4.17 & .86 & .559 & .80 & \\
\hline M3 & & 4,19 & .75 & .735 & .77 & \\
\hline M4 & & 4.22 & 1.04 & .409 & .83 & \\
\hline M5 & & 4.40 & .63 & .700 & .78 & \\
\hline M6 & & 4.19 & .78 & .683 & .78 & \\
\hline M7 & & 4.35 & .76 & .554 & .80 & \\
\hline \multicolumn{7}{|c|}{ Expectation of success in a STEM career } \\
\hline M8 & \multirow{7}{*}{.82} & 3.25 & .98 & .552 & .80 & \\
\hline M9 & & 4.21 & .78 & .582 & .80 & \\
\hline M10 & & 3.89 & .78 & .572 & .80 & \\
\hline M11 & & 3.87 & 1.09 & .432 & .83 & \\
\hline M13 & & 4.13 & .85 & .639 & .79 & \\
\hline M14 & & 4.24 & .73 & .617 & .79 & \\
\hline M15 & & 4.25 & .74 & .705 & .78 & \\
\hline
\end{tabular}

The internal consistency coefficients were calculated as .82 for both perceived value and expectations of success in STEM careers components (Table 6). The internal consistency coefficient of the whole scale was found to be .87. The values obtained for the two components and the whole scale were greater than .70, would be indicated that the adapted scale was reliable. 
Table 6 shows that the reliability coefficients would slightly increase by removing item 4 from the perceived value component and item 11 from the expectations of success in STEM careers component. However, considering that these items did not result in significant changes in the fit indices obtained from CFA and their exclusion would not have led to a significant increase in reliability, it was decided to retain both items in order to maintain as much consistency with the original scale as possible. The results also showed that the corrected-item correlations ranged from .41 to .74 for the perceived value component and from .43 to .71 for the expectations of success in STEM careers. Since the threshold value for the corrected-item total correlations is .30, it can be stated (Büyüköztürk, 2007) that the items under each component adequately measured the desired construct.

\section{DISCUSSION and CONCLUSION}

In the educational context, the expectancy-value theory stipulates that students' motivation for success and behaviors (preferences) are a function of their beliefs (expectations) about their abilities and perceived importance (value) of a particular task (Wigfield, Tonks, \& Klauda, 2009). Thus, the development of interest in a field, including that in a future career, is only possible by increasing the values and expectations of students (Hidi \& Renninger, 2006). Therefore, students' expectations and values concerning STEM are important when examining their STEM orientation and choices (Svoboda, Rozek, Hyde, Harackiewicz, \& Destin, 2016). When a student's expectations regarding their success in and value of STEM fields are high, it is more likely that he/she would make further efforts in STEM fields and graduate from the related education programs. Otherwise, the opposite can be seen (Appianing \& Van Eck, 2018). Therefore this study aimed to adapt VESAS developed by Appianing and Van Eck (2018) to determine individuals' motivation for STEM.

The analysis of the data obtained from the administration of the scale was conducted by CFA. Considering that CFA is a method that enables the validation of a previously formed structure with the available data from a theoretical basis, the factor structure of the adapted scale was found to be adequate for this analysis (Çapık, 2014; Çokluk, Şekercioğlu, \& Büyüköztürk, 2012). According to the results of CFA, some items provided a good fit ( $\mathrm{x}^{2} / \mathrm{df}-2.92$, SRMR.080 , NFI-.91, IFI-.94, RMSEA-.09, NNFI-.92, CFI-.93, GFI-.87, AGFI-.82) while others only indicated an acceptable fit; thus, possible modifications were explored. After obtaining expert opinion, item 12 (I feel that I will have something to be proud of as a STEM expert), which tended to load on both components at the same time, was removed from the scale, and CFA was repeated for the remaining 14 items. The results of the second CFA revealed a good fit for all index values ( $\mathrm{x}^{2} / \mathrm{df}-2.1$, RMSEA-.75, CFI-.97, GFI-.90, AGFI-.85, SRMR-.058, IFI-.97, NFI.-.94, NNFI-.96) and confirmed that the data obtained from the Turkish version of the scale complied with the theoretical structure of the original tool.

After verifying the construct validity of the scale, Cronbach's alpha internal consistency coefficient was examined for the reliability of each component and the whole scale. The internal consistency coefficients were calculated as .82 for both perceived value and expectations of success in STEM careers components, and .87 for the whole scale. Cronbach's alpha value varies between different disciplines or fields of study in the social sciences, the .70 threshold offered by Nunally (1978) is accepted. Considering that this coefficient exceeded the threshold value of .70 in all calculations, it was concluded that the factors of the scale and the scale itself were reliable as a measurement instrument.

In conclusion, this study may be successfully implemented the adaptation of VESAS to Turkish culture, which aims to determine the individuals' motivations related to STEM, and confirmed the validity and reliability of the adapted version through relevant analyses. The importance of STEM fields is increasing day by day, and considering that students' career choices mostly 
depend on their persistence, performance, and motivation in the related fields, it is necessary to measure students' motivation toward STEM (Appianing \& Van Eck, 2018). When the studies in Turkey were examined, no scale was found based on the expectancy-value theory to measure STEM motivation. Thus, the adapted scale has an important place as it fills a gap in the literature by acting as a guide for future research about expectancy-value.

STEM is a new educational approach in Turkey; therefore, the shortage of pre-service teachers receiving effective STEM education created a limitation for this study. It is considered that repeating the study with a larger number of pre-service teachers will contribute to the validity and reliability of the this scale. In addition, it is highly recommended that investigation on the motivation of STEM education based on the expectation-value theory should be diversified at different levels (primary and secondary schools).

\section{Acknowledgements}

This scale was adapted from the STEM Value-Expectancy Assessment Scale (VESAS) developed by Appianing and Van Eck (2018). The authors would like to thank Appianing and Van Eck for allowing their scale to be adapted.

\section{Declaration of Conflicting Interests and Ethics}

The authors declare no conflict of interest. This research study complies with research publishing ethics. The scientific and legal responsibility for manuscripts published in IJATE belongs to the author(s).

\section{ORCID}

Arif Aç1ksöz https://orcid.org/0000-0002-6770-3777
Yakup Özkan https://orcid.org/0000-0002-2757-8123
İlbilge Dökme (D) https://orcid.org/0000-0003-0227-6193

\section{REFERENCES}

Akbaba, S. (2006). Eğitimde motivasyon [Motivation in education]. Kazım Karabekir Eğitim Fakültesi Dergisi, 13, 343-361.

Akgündüz, D., Aydeniz, M., Çakmakçı, G., Çavaş, B., Çorlu, M.S., Öner, T., \& Özdemir, S. (2015). STEM eğitimi Türkiye raporu: Günün modası mı yoksa gereksinim mi? [STEM education Turkey Report: Fashion of the day or need?]. İstanbul Aydın Üniversitesi

Altunel, M. (2018). STEM eğitimi ve Türkiye: Firsatlar ve riskler [STEM education and Turkey: Opportunities and risks]. SETA Perspektif, 207, 1-7.

Ananiadou, K., \& Claro, M. (2009). 21st Century Skills and Competences for New Millennium Learners in OECD Countries. OECD Education Working Papers, No. 41, OECD Publishing.

Appianing, J., \& Van Eck, R.N (2018). Development and validation of the Value-Expectancy STEM Assessment Scale for students in higher education. International Journal of STEM Education, 5(24), 1-16.

Bandura, A. (1995). Self-Efficacy in Changing Societies. Cambridge University Press. Retrieved July 19, 2019, from https://www.researchgate.net/

Barutçu, T. (2017). Beklenti-değer temelli ögretimde yazma becerileri ve motivasyon ilişkisi [The relation between writing skills and motivation in teaching based upon the expectancy-value] (Doctoral thesis). Available from YÖK National Thesis Center database. (Thesis No: 485941).

Breiner, J., Harkness, S., Johnson, C., \& Koehler, C. (2012). What is STEM? A discussion about conceptions of STEM in education and partnerships. School Science and Mathematics, 112(1), 3-11. 
Burak, S. (2014). Motivation for instrument education: A Study with the perspective of expectancy-value and flow theories. Eurasian Journal of Educational Research, 55, 123 136.

Büyüköztürk, Ş. (2007). Sosyal bilimler için veri analizi el kitabı [Handbook of data analysis for social sciences]. Ankara: Pegem A Yayıncilık

Bybee, R. W. (2010). What is STEM education?. Science, 329(5995), 996.

Chen, J.A., \& Dede, C.J. (2011). Youth STEM motivation: Immersive Technologies to engage and empower underrepresented students. STEM Learning and Research Center: Retrieved June 27, 2019, from http://stelar.edc.org/

Çapık, C. (2014). Geçerlik ve güvenirlik çalışmalarında doğrulayıcı faktör analizinin kullanımı [Use of confirmatory factor analysis in validity and reliability studies]. Anadolu Hemşirelik ve Sağlık Bilimleri Dergisi, 17(3), 196-205.

Çokluk, Ö., Şekercioğlu, G., \& Büyüköztürk, Ş. (2012). Sosyal bilimler için çok değişkenli istatistik: SPSS ve LISREL uygulamalart [Multivariate statistics for social sciences: SPSS and LISREL applications]. Ankara: Pegem Akademi.

Eccles, J.S. (2005). Subjective task value and eccles et al. model of achievement-related choices. In A.J. Elliot \& C.S. Dweck (Eds.). Handbook of competence and motivation, 105-121.

Eccles, J.S. (2005). Studying gender and ethnic differences in participation in math, physical science and information technology. New Directions for Child and Adolescent Development, 110, 7-14.

Eccles, J. S., \& Wigfield, A. (2002). Motivational beliefs, values, and goals. Annual Review of Psychology, 53, 109-132.

Ekeh, P.U., \& Njoku, C. (2014). Academic optimism, students' academic motivation and emotional competence in an inclusive school setting. European Scientific Journal. 10(19), 127-141.

Gråstén, A. (2016) Children's expectancy beliefs and subjective task values through two years of school-based program and associated links to physical education enjoyment and physical activity. Journal of Sport and Health Science, 5(4), 500-509.

Haciömeroğlu, G., \& Bulut, A.S. (2016). Integrative STEM Teaching Intention Questionnaire: A validity and relaibility study of the Turkish form. Eğitimde Kuram ve Uygulama, 12(3), 654-669.

Harackiewicz, J.M., Rozek, C.S., Hulleman, C.S., \& Hyde J.S. (2012). Helping Parents to Motivate Adolescents in Mathematics and Science: An Experimental Test of a UtilityValue Intervention. Psychological Science, 23(8), 899-906.

Hidi, S., \& Renninger, K. A. (2006). The four-phase model of interest development. Educational Psychologist, 41, 111-127.

Hossain M., \& Robinson, M.G. (2012). How to motivate US students to pursue STEM (science, technology, engineering and mathematics) careers. US-China Educ Rev A, 4, 442-451.

Hambleton, R.K., \& Patsula, L. (1999). Increasing the validity of adapted tests: Myths to be avoided and guidelines for improving test adaptation practices. Journal of Applied Testing Technology, 1(1), 1-30.

Irvine, J. (2018). A framework for comparing theories related to motivation in education. Research in Higher Education Journal, 35, 1-30.

Joseph, C.H., Anikelechi, I.G., \& Marumo, P. (2019). Academic motivation of school going adolescents: Gender and age difference. Gender and Behaviour, 17(1), 12306-12315.

Kline R.B. (2005). Principles and Practice of Structural Equation Modeling. New York: Guilford Press, 154-186.

Lotta C.L., \& Teresa N.M. (2011). 21st Century skills: Prepare students for the future. Kappa Delta Pi Record., 47(3), 121-123. 
MEB (2016). STEM Eğitimi Raporu [STEM education report]. Ankara

MEB (2017). STEM Ĕgitimi Ögretmen El Kitabı [STEM education teacher handbook]. Ankara

Meyer, J., Fleckenstein, J., \& Köller, O. (2019). Expectancy value interactions and academic achievement: Differential relationships with achievement measures. Contemporary Educational Psychology, 58, 58-74.

Mitchell T.R. (1982). Motivation: New directions for theory, research, and practice. Academy of Management Review, 7(1), 80-88.

Morrison, J. (2006). TIES STEM education monograph series, attributes of STEM education. Baltimore, MD: Teaching Institute for Excellence in STEM. Partner for Public Education: Retrieved July 15, 2019, from https://www.partnersforpubliced.org/

Nagy, G., Trautwein, U., Baumert, J., Köller, O., \& Garrett, J. (2006). Gender and Course Selection in Upper Secondary Education: Effects of academic self-concept and intrinsic value. Educational Research and Evaluation, 12(4), 323-345.

National Science Board. (2007). A National action plan for addressing the critical needs of the U.S. science, technology, engineering, and mathematics education system. National Science Foundation. https://www.nsf.gov/pubs/2007/nsb07114/nsb07114.pdf (accessed on $16 / 07 / 2019)$

Nunnally, J.C. (1978). Psychometric theory. New York: McGraw-Hill.

Onaran, O. (1981). Çalışma yaşamında güdülenme kuramları [Motivation theories in working life]. Ankara: Ankara Üniversitesi Siyasal Bilgiler Fakültesi Yayınları

PCAST (2010). Prepare and Inspire: K-12 Education in Science, Technology, Engineering, and Math (STEM) Education for America's Future Executive Report. Washington National Science Foundation: Retrieved July 13, 2019, https://nsf.gov/

Partridge, J., Brustad, R., \& Stellino, M.B. (2013). Theoretical perspectives: Eccles' expectancy-value theory. Advances in Sport Psychology, 3, 269-292.

Putwain, D.W., Nicholson, L.J., Pekrun, R., Becker, S., \& Symes, W. (2019). Expectancy of success, attainment value, engagement, and Achievement: A moderated mediation analysis. Learning and Instruction, 60, 117-125.

Romine, W.L., \& Sadler, T.D. (2016). Measuring changes in interest in science and technology at the college level in response to two instructional interventions. Reserch in Science Education, 46(3), 309-327.

Rosenzweig, E.Q., \& Wigfield, A. (2016). STEM motivation interventions for adolescents: A promising start but further to go. Educational Psychologist, 51(2), 146-163.

Saavedra, A. R., \& Opfer, D. (2012). Learning 21 st-century skills requires $21^{\text {st }}$ century teaching. Phi Delta Kappan, 94(2), 8-13.

Sanders, M. (2009). Stem, STem Education, STEMmania. Technology Teacher, 68(4), 20-26.

Sarısepetçi, M. (2018). An adaptation of the success motivation scale based on the expectationvalue theory. International Journal of Education Science and Technology, 4(1), 28-40.

Schermelleh-Engel, K., Moosbrugger, H., \& Müler, H. (2003). Evaluating the fit of structural equation models: Tests of significance and descriptive Goodness-Of-Fit Measures. Methods Of Psychological Research Online, 8(2), 23-74.

Sümer, N. (2000). Yapısal eşitlik modelleri: Temel kavramlar ve örnek uygulamalar [Structural equation models: Basic concepts and sample applications]. Türk Psikoloji Yazıları, 3(6), 49-74.

Svoboda, R.C., Rozek C.S., Hyde, J.S., Harackiewicz, J.M., \& Destin, M. (2016). Understanding the relationship between parental education and STEM course taking through identity-based and expectancy-value theories of motivation. AERA Open, 2(3), 1-13. 
Tschannen-Moran, M., \& McMaster, P. (2009). Sources of self-efficacy: Four professional development formats and their relationship to self-efficacy and implementation of a new teaching strategy. The Elementary School Journal, 110(2), 228-245.

Titrek, O., Çetin, C., Kaymak, E., \& Kaşıkçı, M. M. (2018). Academic motivation and academic self-efficacy of prospective teachers. Journal of Education and Training Studies, 6(11a), 77-87.

Tünkler, V. (2018). İlköğretim öğrencilerinin sosyal bilgiler dersine yönelik yeterlik beklentileri ve değer algılarının incelenmesi [Examining the adequacy expectations and value perceptions of primary school students towards social studies course]. Hacettepe University Journal of Education, 34(4), 1107-1120.

Wang, X. (2013). Why students choose STEM majors: Motivation, high school learning, and postsecondary context of support. American Educational Research Journal, 50(5), 10811121.

West, M. (2012). STEM education and the workplace. Office of the Chief Scientist, Occasional Paper Series, Issue 4. Canberra: Australian Goverment. Retrieved July 20，2019, https://www.chiefscientist.gov.au/

Wigfield, A. (1994). Expectancy-value theory of achievement motivation: A developmental perspective. Educational Psychology Review, 6(1), 49-78.

Wigfield, A., \& Eccles, J. S. (2000). Expectancy-value theory of achievement motivation. Contemporary Educational Psychology, 25, 68-81.

Wigfield, A., Tonks, S., \& Klauda, S. L. (2009). Expectancy-value theory. In K. Wentzel \& A. Wigfield (Eds.). Handbook of motivation at school, 55-75. New York, NY: Routledge.

Yazıcı, H. (2009). Öğretmenlik mesleği, motivasyon kaynakları ve temel tutumlar: Kuramsal bir bakış [Teaching profession, sources of motivation and basic attitudes: A theoretical perspective]. Kastamonu Eğitim Dergisi, 17(1), 33-46.

Y1ldırım, B. (2018). Türkiye'nin 2023, 2053 ve 2071 hedefleri için STEM eğitim raporu. [Turkey's 2023, 2053 and 2071 targets for STEM education report]. Muş Alparslan Üniversitesi. Retrieved June 20, 2019, https://www.researchgate.net/ 